\title{
Role of Riboflavin and Thiamine in Induced Resistance Against Charcoal Rot Disease of Soybean
}

Abdel-Monaim, M.F.

Plant Pathology Research Institute, Agricultural Research Center, Giza, Egypt.

Charcoal rot (Macrophomina phaseolina (Tassi) Goidanich) of Csoybean (Glycine $\max$ (L.) Merr.) is a disease of economic significance throughout the world. Pathogenicity of 14 isolates of Macrophomina phaseolina was tested on soybean cv. Giza 21 under greenhouse conditions. They capable to infect soybean plants caused charcoal rot on the basil stem with various degrees of diseases severity. Isolate S13 caused the highest charcoal rot severity $(60 \%)$ followed by isolates S11 and S8 (57.9 and $56.3 \%$, respectively).

The positive effect of two inducer chemicals, i.e riboflavin (vitamin B2) and thiamine (vitamin B1) on the induction of systemic resistance in soybean against charcoal rot disease as well as biochemical changes associated with these treatments in soybean plants was recorded.

Under greenhouse conditions, the dose effect of 0.1 to $15 \mathrm{mM}$ riboflavin and thiamine showed that $2.5 \mathrm{mM}$ of riboflavin and $5 \mathrm{mM}$ of thiamine was sufficient for maximum induction of resistance; higher concentration did not increase the effect. On the other hand, plants treated with riboflavin and thiamine and inoculated with pathogen grow higher than plants treated with sterilized distilled water (SDW) and inoculated with pathogen, while increased fresh and dry weight of soybean plants. At $10 \mathrm{mM}$ concentration of riboflavin and thiamin recorded the highest dry and fresh weights. In time course observation, it was observed that riboflavin and thiamine treated soybean plants were inducing resistance one day after treatment and reached its maximum level from 5 to 7 days in case of riboflavin and 6-8 days in case of thiamine and then decreased.

Under field conditions, the percentages of damping-off, root rot and/or charcoal rot severity were significantly reduced due to soaking the seeds in any of riboflavin and thiamine before sowing in both trial seasons (2008-2009 and 2009-2010). Also, these treatments significantly increased nodule numbers plant ${ }^{-1}$, fresh and dry weight of nodules plant ${ }^{-1}$ in both experimental seasons. Generally, thiamine gave the best results in most cases under greenhouse and field conditions.

In physiological studies, activity of defense-related enzymes, including peroxidase, polyphenol oxidase, phenylalanine ammonia lyase, pathogenesis related (PR) protein (chitinase), were increased in inoculated and non-inoculated plants treated with the thiamine and riboflavin individually, during the experimental period. In general, activity of these enzymes begins to accumulate after two days of treatment and reached maximum levels at 8, 6, 8 and 8 days for PO, PPO, PAL and chitanase, respectively, then the activities of these 
enzymes were decreased progressively. On the other hand, total phenols and lignin increased in soybean plants inoculated with $\mathrm{M}$. phaseolina and treated with thiamine and riboflavin. The highest accumulation of phenols was recorded 6th days from application, while lignin recorded the highest level at 10th days from application. These results suggested that these chemicals may be play an important role in controlling the soybean charcoal rot disease, though they have induction of systemic resistance in soybean plants.

Keywords: Soybean, charcoal rot, Thiamine, Riboflavin, induced resistance.

Soybean (Glycine $\max (\mathrm{L}$.$) Merr.) is considered as one of the main oil crops all$ over the world. It occupies special importance in Egypt because it contains $20 \%$ oil of dry seed weight, and being an important source of protein, which reaches $40 \%$ of dry seed weight along with calcium, iron, carotene, thiamine and ascorbic acid (ElAbady et al., 2008). Also, soybean plants like many other legumes are capable of fixing and utilized atmospheric nitrogen through symbiotic relationship with Rhizobium bacteria at the root of the crops. The plant thus improves soil fertility and economizes crop production not only for themselves but also for the next crops grown in rotation especially cereal crops (Nassiuma and Wasike, 2002).

Soybean is subjected attack by many diseases caused by fungi, bacteria, viruses, mycoplasma and nematodes (Sweets, 2008). Macrophomina phaseolina (Tassi) Goidanich is an important soil borne pathogen of soybean caused major economic loss in seeds yield (Mengistu et al., 2007 and El-Barougy et al., 2009). The disease it causes, charcoal rot, is most evident during the reproductive phases of plant growth, although the fungus can be isolated from plant roots throughout the growing season. Visible symptoms of the disease in the field are most apparent under conditions that reduce plant vigor, such as poor soil fertility, high seeding rates, low soil water, high temperatures and root injury (Kendig et al., 2000).

The most successful control strategy used for charcoal root rot in soybean has been seed treatment with fungicides (Hewidy et al., 2003). However, there are series of problems with applying this product such as high cost, environmental pollution, breaking up the ecological balance of the soil (González, 2006). For these reasons, its use is prohibited in Europe and the United States and will be prohibited in developing countries in 2015 according to the Montreal Protocol (Karliner, 1997).

Therefore, alternative control methods are needed for managing this pathogen. Several alternative measures are being tested, natural resources such as biological control (El-Barougy et al.,2009), plant extracts and soil solarization (Dubey et al., 2009) chemical inducers (El-Baz, 2007), resistant cultivars (Mengistu et al., 2007), planting dates (Todd, 1993), crop rotation (Francl et al., 1988) found to be good and safe means of diseases control especially the soilborne diseases.

In recent years, the importance of vitamins as nutrients and as control agent for different diseases has been demonstrated (Dong and Beer, 2000). Ahn et al. (2005) demonstrated that thiamine (vitamin B1) induces SAR and vitamin B1 functions as an activator of plant disease resistance. They described that thiamine treated rice,

Egypt. J. Phytopathol., Vol. 39, No. 1 (2011) 
Arabidopsis thaliana and vegetable crops showed resistance to fungal, bacterial and viral infections and that thiamine treatment induced the transient expression of PRgenes in rice and other plants through the $\mathrm{SA}$ and $\mathrm{Ca}^{+2}$ related signaling pathways.

Riboflavin (vitamin B2) produced by plants and microbes acts as a coenzyme izn many physiological reactions in plants, microbes and animals (Gastaldi et al., 1999). It also participates in antioxidation as well as in peroxidation (Packer et al., 1996). In these processes the production of reactive oxygen intermediates (ROIs) results in an oxidative burst and consequently leads to hypersensitive response (Dong and Beer, 2000). Ryals et al. (1996) and Delaney (1997) presented evidence that riboflavin acts as a novel signaling pathway leading to systemic resistance, activating PR-genes in A. thaliana and tobacco, and induces resistance to pathogens. Our preliminary studies showed that riboflavin causes induced resistance in chickpea against Fusarium wilt and charcoal rot diseases (Saikia et al., 2006).

The present study is planned to evaluate the efficiency of riboflavin and thiamine as safe control means in controlling charcoal rot on soybean.

\section{Materials and Methods}

Isolation, purification and identification of the pathogen:

Macrophomina phaseolina was isolated from soybean plants infected with charcoal rot disease collected from different locations of Minia, Assuit and New Valley governorates. Infected plant tissues bearing fungal sclerotia were selected. The tissue was cut into $5 \mathrm{~mm}$ long and 2-3 $\mathrm{mm}$ thick pieces. They were surface sterilized with $1 \% \mathrm{NaOCl}$ solution for about 2 minutes followed by thoroughly washing with sterilized water. The sterilized pieces were transferred to potato dextrose agar (PDA) medium in $9 \mathrm{~cm}$ diameter Petri plates and incubated at $28 \pm 2{ }^{\circ} \mathrm{C}$ for 5 days. Purification of the isolated fungus was carried out using hyphal tip technique as described by Dhingra and Sinclair (1985). The isolated fungus was identified according to their morphological characters according to Barnett and Hunter (1986). Subcultures of the obtained isolates were then kept on PDA slants and stored at $4{ }^{\circ} \mathrm{C}$ for further studies.

\section{Preparation of fungal inoculum:}

The inoculum of $M$. phaseolina was prepared from one week old culture grown on $100 \mathrm{ml}$ Potato Dextrose (PD) broth medium in flask $(500 \mathrm{ml})$ and incubated at $28 \pm 2$ ${ }^{\circ} \mathrm{C}$ according to Muthomi et al. (2007). The content of the flask was homogenized in a blender for one min. The resulted cultures were used for soil infestation in a greenhouse experiment for studying the pathogenicity test.

\section{Greenhouse experiments:}

Pathogenicity tests:

Pathogenicity test of M. phaseolina (14 isolates) was carried out at New Valley Agric. Res. Station using soybean Giza 21 cultivar in plastic pots (30-cm-diam.) containing sterilized sandy loam soil. Soybean seeds were surface sterilized by immersing them in $1 \%$ sodium hypochlorite solution for 2 min then washed several times with sterilized water. Ten seeds were sown in each pot and maintained in the greenhouse. After fifteen days of sowing, pots were inoculated with $100 \mathrm{ml}$ 
homogenate culture $\left(10^{3} \mathrm{CFU} / \mathrm{ml}\right)$ prepared before, using inoculation method described by Saikia et al. (2006). Four pots were used for each isolate as replicates, each pot content 5 seedlings. The control was inoculated with the same amount of autoclaved PD medium without fungal inoculum.

Disease severity index was determined after 45 days from inoculation with a diseases scale proposed by Mengistu et al. (2007) and diseases severity (\%) was calculated using the following formula:

Where:

Disease severity $(\%)=\sum(\mathrm{n}$ x v) $/ 5 \mathrm{~N}$ X 100

$\mathrm{n}=$ number of plants in each category

$\mathrm{v}=$ numerical values of symptoms category

$\mathrm{N}=$ total number of numerical values of symptoms categories.

Effectiveness of thiamine and riboflavin for controlling charcoal rot disease under greenhouse condition:

Fifteen days old seedlings ( 5 seedling /pot) were injected with $50 \mu$ of thiamine and riboflavin by sterile syringe at the base of stem with different concentrations $(0.0,0.1,0.25,0.5,1.0,2.5,5.0,10.0$ and $15 \mathrm{mM})$. Three days after treatment, pots were inoculated with homogenate suspension of $M$. phaseolina isolate $\left(10^{3} \mathrm{cfu} \mathrm{ml}^{-1}\right.$, $100 \mathrm{ml}^{-1}$ pot). Four pots were used as a replicate. The whole experiment was designed as complete randomized block design (CRBD). Disease severity (\%) was examined for the next 45 days by the formula as suggested by Mengistu et al. (2007) described. Also, fresh and dry weights of survival plans $\left(\mathrm{g} \mathrm{plant}^{-1}\right)$ were recorded in the end of the experiment.

Time course effect of thiamine and riboflavin:

Dose effect of thiamine and riboflavin showed that concentrations of 5 and 2.5 $\mathrm{mM}$, respectively was effective, so this concentration was used for this study. Fifteen days old soybean seedlings were injected with $50 \mu \mathrm{l}$ of thiamine and riboflavin, individually by sterile syringe at the base of stem; after 0 to 11 days of treatment soils of the seedlings were infested with the homogenate suspension of $M$. phaseolina isolate $\left(10^{3} \mathrm{CFU} \mathrm{ml} \mathrm{m}^{-1}, 100 \mathrm{ml}^{-1}\right.$ pot). The disease severity (\%) was recorded as mentioned above.

Field experiments:

The experiment was carried out in the Experimental Farm of New Valley Agric. Res. Station during two successive growing summer seasons; 2009 and 2010, for controlling damping-off and charcoal rot diseases of soybean in naturally infested field. The seeds were soaked in thiamine and riboflavin at concentration 5 and 2.5 $\mathrm{mM}$, respectively for $20 \mathrm{~min}$. In control treatment, seeds were soaked in only water for the same time. The treatments were distributed in a complete randomized block design with four replicates, the experimental plot area was $10.5 \mathrm{~m}^{2}(3 \times 3.5 \mathrm{~m})$ containing five rows, each row was $3.5 \mathrm{~m}$ in length and distance between rows was $60 \mathrm{~cm}$. All treatments were sown in hills $20 \mathrm{~cm}$ apart on both sides of row ridge and two seeds per hill (plant population $=140,000$ plants/fed). All recommended agricultural practices were adopted throughout the two seasons.

Egypt. J. Phytopathol., Vol. 39, No. 1 (2011) 
Percentage of damping-off was calculated 30 days after planting. Charcoal rot severity was also recorded on a random sample of plants of the plots (20 plants) three months after planting according to Mengistu et al. (2007).

At 60 days after cultivation, plants were uprooted (20 plant plot $^{-1}$ ) to estimate number, fresh and dry weight of nodules plant ${ }^{-1}$.

At harvest time a sample of twenty randomly plants from each experimental unit were taken and the following characteristics were recorded; plant height, number of branches and pods plant ${ }^{-1}$ and 100- seed weight. Seed yield $\left(\mathrm{kg} \mathrm{fed}^{-1}\right)$ was determined from the rows of each experimental unit. Seed oil content (\%) estimated by taking seed samples of dried seeds of each plot, cleaned and ground into very fine powder by grinder to determine seed oil percentage as described by A.O.A.C. (1990) using Soxhelt apparatus and petroleum ether as an organic solvent. Seed crude protein percentage was estimated according to A.O.A.C. (1990).

Biochemical changes associated with thiamine and riboflavin treatment:

To observe the accumulation of peroxidase (PO), polyphenol oxidase (PPO), chitanase, phenylalanine ammonia lyase (PAL) and content each of phenolic compounds and lignin, 15 days old seedlings were injected with thiamine $(5 \mathrm{mM})$ and riboflavin $(2.5 \mathrm{mM})$ and sterilized distilled water (SDW), $50 \mu \mathrm{plant}^{-1}$. After 2 days from treatment plants, pot soils infested were inoculated with $100 \mathrm{ml}$ of $M$. phaseolina homogenate suspension per pot. The following treatments were made (i) control- treated with SDW only; (ii) pathogens control- treated with M. phaseolina; (iii) plant treated with thiamine and after 2 days inoculated with the pathogen and (v) plant treated with riboflavin and after 2 days inoculated with the pathogen. The peroxidase (PO), polyphenol oxidase (PPO), chitanase, phenylalanine ammonia lyase (PAL) activities and content each of phenolic compounds and lignin were estimated after $0,2,4,6$ and 8 days from inoculation. One gram of plant tissue was homogenized in $10 \mathrm{ml}$ of ice-cold $50 \mathrm{mM}$ potassium phosphate buffer ( $\mathrm{pH}$ 6.8) containing $1 \mathrm{M} \mathrm{NaCl}, 1 \%$ polyvinylpyrrolidone, (PVP), $1 \mathrm{mM}$ EDTA and $10 \mathrm{mM} \beta$ mercaptoethanol (Biles and Martyn, 1993). After filtration through cheesecloth, the homogenates were centrifuged at $8000 \mathrm{rpm}$ at $4^{\circ} \mathrm{C}$ for $25 \mathrm{~min}$. The supernatants (crude enzyme extract) were stored at $-20^{\circ} \mathrm{C}$ or immediately used for determination PO, PPO, chitanase and PAL enzymes activities and total protein. In the case of every enzyme under investigation, each treatment consisted in four replicates (3 plants/ replicate) and two spectrophotometric readings using Milton Roy Spectrophotometer (Milton Roy spectronic1201) were taken per replicate. The experiment for bioassays was repeated twice in time.

Peroxidase activity:

The enzyme activity of PO was determined a direct spectrophotometrically method (Hammerschmidt et al., 1982) using guaiacol as common substrate for peroxidases. The reaction mixture consisted of $0.2 \mathrm{ml}$ crude enzyme extract and 1.40 $\mathrm{ml}$ of a solution containing guaiacol, hydrogen peroxide $\left(\mathrm{H}_{2} \mathrm{O}_{2}\right)$ and sodium phosphate buffer $\left(0.2 \mathrm{ml} 1 \%\right.$ guaiacol+0.2 $\mathrm{ml} 1 \% \mathrm{H}_{2} \mathrm{O}_{2}+1 \mathrm{ml} 10 \mathrm{mM}$ potassium phosphate buffer), was incubated at $25^{\circ} \mathrm{C}$ for $5 \mathrm{~min}$ and the initial rate of increase in 
absorbance was measured over $1 \mathrm{~min}$ at $470 \mathrm{~nm}$ using spectrophotometer. Peroxidase activity was expressed as units of $\mathrm{PO} / \mathrm{mg}$ protein (Urbanek et al., 1991).

Polyphenoloxidase activity:

The activity of PPO was determined by adding $50 \mu \mathrm{l}$ of the crude extract to $3 \mathrm{ml}$ of a solution containing $100 \mathrm{mM}$ potassium phosphate buffer, $\mathrm{pH} 6.5$ and $25 \mathrm{mM}$ pyrocatechol. The increase of absorbance at $410 \mathrm{~nm}$, for $10 \mathrm{~min}$ at $30^{\circ} \mathrm{C}$, was measured (Gauillard et al., 1993). One PPO unit was expressed as the variation of absorbance at $410 \mathrm{~nm}$ per milligram of soluble protein per minute.

Phenylalanine ammonia-layse activity:

Phenylalanine ammonia-layse (PAL) activity was determined following the direct spectrophotometric method adapted by Cavalcanti et al. (2007). Two hundred microlitres of the crude enzyme extract previously dialyzed overnight with $100 \mathrm{mM}$ Tris- $\mathrm{HCl}$ buffer, $\mathrm{pH} 8.8$, were mixed to obtain a solution containing $200 \mu \mathrm{l} 40 \mathrm{mM}$ phenylalanine, $20 \mu \mathrm{l} 50 \mathrm{mM} \beta$-mercaptoethanol and $480 \mu 100 \mathrm{mM}$ Tris- $\mathrm{HCl}$ buffer, $\mathrm{pH}$ 8.8. After incubation at $30^{\circ} \mathrm{C}$ for $1 \mathrm{~h}$, the reaction stopped by adding 100 $\mu \mathrm{l} 6 \mathrm{~N} \mathrm{HCl}$. Absorbance at $290 \mathrm{~nm}$ was measured and the amount of trans-cinnamic acid formed was evaluated by comparison with a standard curve (0.1-2 mg transcinnamic acid/ml) and expressed as units of PAL $\min ^{-1} \mathrm{mg}$ protein ${ }^{-1}$.

Chitinase activity:

The Chitinase activity was determined using the method described by Wirth and Wolf (1992). High polymeric carbomethyl-substituted chitin labeled covalently Remazol Brilliant Violet 5R (CM-Chitin*-RBV. Comp. Loewe Biochemica) was used as substrate. The reaction mixture was as follows: $0.50 \mathrm{ml} 0.01 \mathrm{M} \mathrm{Na}$-Acetate buffer $\mathrm{pH} 5.2$ with $5 \%(\mathrm{v} / \mathrm{v})$ glycerin, $0.25 \mathrm{ml}$ plant extract and $0.25 \mathrm{ml}$ dye labeled substrate CM-*RBV solution $(2 \mathrm{mg} / \mathrm{ml})$. Test samples were incubated in a water bath at $37^{\circ} \mathrm{C}$ for $120 \mathrm{~min}$. The enzyme reaction was terminated by adding $0.25 \mathrm{ml} 2$ $\mathrm{N} \mathrm{HCl}$. After centrifugation $(8000 \mathrm{rpm} ; 25 \mathrm{~min})$, supernatants containing soluble, dye labeled degradation products were transferred to cuvet. Absorbency was measured spectrophotometrically at $550 \mathrm{~nm}$; sodium acetate buffer was added to blanks instead of plant extract. Enzyme activity was expressed as enzyme unit/mg protein.

\section{Protein concentration:}

Total protein content of the samples was quantified according to the method described by Bradford (1976).

Determination of phenolic compounds:

To assess phenolic content, $1 \mathrm{~g}$ fresh plant sample was homogenized in $10 \mathrm{ml} 80$ $\%$ methanol and agitated for $15 \mathrm{~min}$. at $70^{\circ} \mathrm{C}$. One $\mathrm{ml}$ of the extract was added to 5 $\mathrm{ml}$ of distilled water and $250 \mu \mathrm{l}$ of $1 \mathrm{~N}$ Folin-Ciocalteau reagent and the solution was kept at $25^{\circ} \mathrm{C}$. The absorbance was measured with a spectrophotometer at $725 \mathrm{~nm}$. Catechol was used as a standard. The amount of phenolic content was expressed as phenol equivalents in $\mathrm{mg} \mathrm{g}^{-1}$ fresh tissue (Saikia et al., 2006 ).

Determination of lignin:

Egypt. J. Phytopathol., Vol. 39, No. 1 (2011) 
One gram plant tissue from each treatment was mixed with $10 \mathrm{~g}$ of trichloroacetic acid (TCA) and incubated at $90^{\circ} \mathrm{C}$. Delignification was stopped by cooling the reaction mixture after $240 \mathrm{~min}$. of reaction time. The reaction vessel was immersed in cold water and $5 \mathrm{ml}$ of cold acetone were added. Suspension was filtered and liquor was evaporated until dark, high consistency liquid without smell of acetone was obtained. Lignin was precipitated by pouring the liquid in $200 \mathrm{ml}$ cod water. Lignin was filtered and washed with warm water several times. After that, lignin was air-dried overnight at $4^{\circ} \mathrm{C}$ then weight (Liken and Perdih, 1999).

Statistical analysis:

In all experiments the least significant difference (LSD) at 0.05 confidences was determined according to Gomez and Gomez (1984).

\section{R e s u l t s}

Isolation trails from rotted plants collected from different localities of Minia, Assuit and New Valley governorates yielded a fungus which was identified as Macrophomina phaseolina.

Results illustrated in Fig. (1) show that all the obtained isolates (14 isolates) able to attack soybean plants caused charcoal rot on the basil stem with various degrees of diseases severity. M. phaseolina isolate S13 caused the highest charcoal rot severity (60\%) followed by isolates S11 and S8 (57.9 and 56.3\%, respectively).

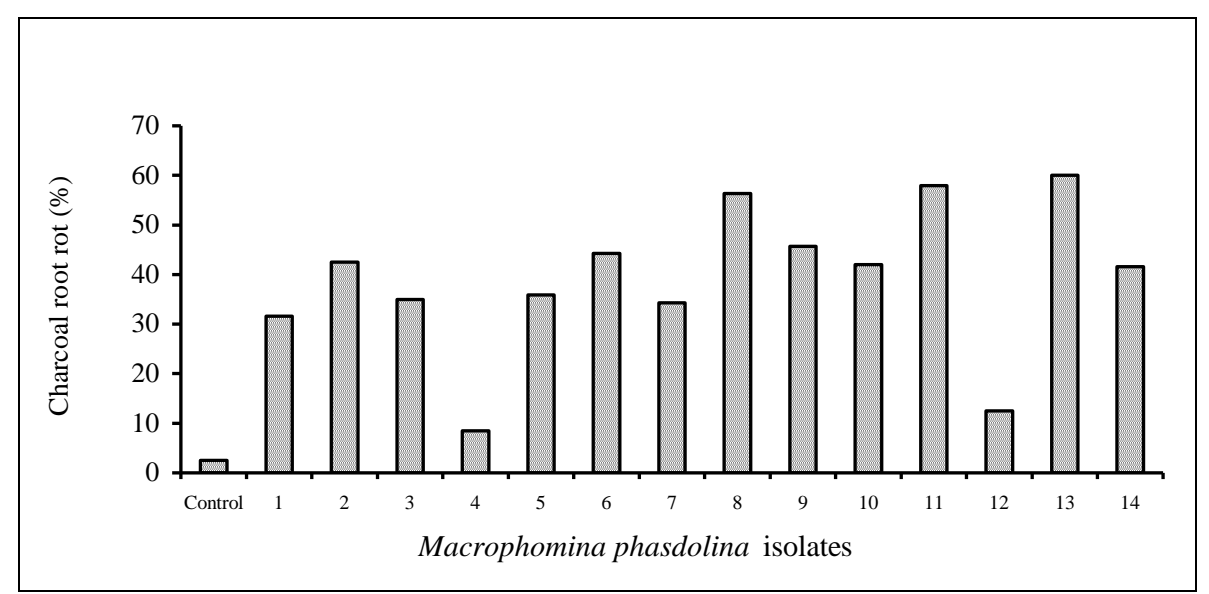

Fig.1. Pathogenicity tests of $M$. phaseolina isolates, isolated from natural diseased soybean plants.

While the other isolates except S4 and S12 caused moderate infection of soybean plants (31.6-45.7\%). Isolates S4 and S12were the weak ones for cause charcoal rot (8.5 and $12.5 \%$, respectively). Charcoal rot (\%) was recorded after 45 days from inculcation according to Mengistu, et al. (2007) based on 0-5 scale according to percentage of foliage yellowing or necrosis $(0=0 \%, 1=1-25 \%, 2=$ $26-50 \%, 3=51-75 \%, 4=$ up to $76 \%, 5=$ completely dead plants), Disease severity $(\%)=\sum(\mathrm{n} \mathrm{X} \mathrm{v}) / 5 \mathrm{~N} \mathrm{X} 100(\mathrm{LSD}$ at $0.05=3.67)$

Egypt. J. Phytopathol., Vol. 39, No.1 (2011) 
Effectiveness of riboflavin and thiamine for controlling charcoal rot disease under greenhouse conditions:

A mark reduction in infection by $M$. phaseolina was observed in riboflavin and thiamine treated soybean plants, while SDW treated plants (control) exhibited heavy infection (Table 1). The disease severity in treated plants with riboflavin and thiamine was significantly lower than those plants treated with SDW. The dose effect of riboflavin and thiamine showed that the concentration of 2.5 and $5 \mathrm{mM}$,

Table 1. Effect of treating soybean seedlings with eight concentrations of riboflavin and thiamine on charcoal rot disease, fresh and dry weight plant $^{-1}$ under artificial infection by $M$. phaseolina, under greenhouse conditions.

\begin{tabular}{|l|l|l|c|c|c|}
\hline Treatments & $\begin{array}{l}\text { Concen. } \\
(\mathrm{mM})\end{array}$ & $\begin{array}{l}\% \\
\text { Charcoal rot }\end{array}$ & $\begin{array}{l}\text { \% } \\
\text { Protection }\end{array}$ & $\begin{array}{l}\text { Fresh weight } \\
\left(\mathrm{g} \mathrm{plant}^{-1}\right)\end{array}$ & $\begin{array}{l}\text { Dry weight } \\
\left(\mathrm{g} \mathrm{plant}^{-1}\right)\end{array}$ \\
\hline \multirow{5}{*}{ Riboflavin } & 0.1 & 55.3 & 12.5 & 1.125 & 0.328 \\
\cline { 2 - 6 } & 0.25 & 47.0 & 25.6 & 1.561 & 0.492 \\
\cline { 2 - 6 } & 0.5 & 35.0 & 44.6 & 1.735 & 0.543 \\
\cline { 2 - 6 } & 1.0 & 28.9 & 54.3 & 1.998 & 0.594 \\
\cline { 2 - 6 } & 2.5 & 22.7 & 64.1 & 2.343 & 0.705 \\
\cline { 2 - 6 } & 5 & 22.7 & 64.1 & 2.370 & 0.713 \\
\cline { 2 - 6 } & 10 & 22.7 & 64.1 & 2.446 & 0.729 \\
\hline \multirow{5}{*}{ Thiamine } & 15 & 25.3 & 60.0 & 2.329 & 0.689 \\
\cline { 2 - 6 } & 0.1 & 50.2 & 20.6 & 1.562 & 0.493 \\
\cline { 2 - 6 } & 0.25 & 41.9 & 33.7 & 1.786 & 0.538 \\
\cline { 2 - 6 } & 1.0 & 35.7 & 43.5 & 1.780 & 0.542 \\
\cline { 2 - 6 } & 2.5 & 25.3 & 60.0 & 2.182 & 0.664 \\
\cline { 2 - 6 } & 5 & 18.4 & 70.9 & 2.440 & 0.742 \\
\cline { 2 - 6 } & 10 & 13.3 & 79.0 & 2.561 & 0.726 \\
\hline Control & 13.3 & 79.0 & 2.611 & 0.750 \\
\hline LSD at 0.05 & 14.5 & 77.1 & 2.532 & 0.730 \\
\hline
\end{tabular}

respectively were maximum effective and sufficient for induction of resistance and control of charcoal rot disease (64.1 and $79.0 \%$ protection). Higher concentrations than 2.5 and $5 \mathrm{mM}$ in case of riboflavin and thiamine did not show increase in resistance. However, less than 2.5 and $5 \mathrm{mM}$ concentrations were less effective, which indicated that below of concentration $2.5 \mathrm{mM}$ (riboflavin) and $5 \mathrm{mM}$ (thiamine), it is directly proportional 1 to the reduction of induction of resistance, which recorded 2.446 and $2.611 \mathrm{~g} \mathrm{plant}^{-1}$ fresh weight and 0.729 and $0.750 \mathrm{~g} \mathrm{plant}^{-1}$ dry weight, respectively compared with $0.510 \mathrm{~g}$ plant ${ }^{-1}$ and $0.156 \mathrm{~g}$ dry weight in SDW treatment (control).

Generally, thiamine gave the best protection against infection by $M$. phaseolina and increased fresh and dry weights of soybean plants than riboflavin at all concentrations.

Egypt. J. Phytopathol., Vol. 39, No. 1 (2011) 
Time course effects of riboflavin and thiamine on charcoal rot disease:

The time course resistance in riboflavin and thiamine treated soybean plants became apparent after one day from application and reached maximum level at 5 to 7 days after treatment with riboflavin and 6-8 days after treatment with thiamine (Fig. 2). Charcoal rot resistance declined quickly after the 8 th day in case of treatment with riboflavin and in case of thiamine treatment, it was reduced after the 9th day. The reduction of resistance to charcoal rot disease was higher in case of riboflavin than thiamine.

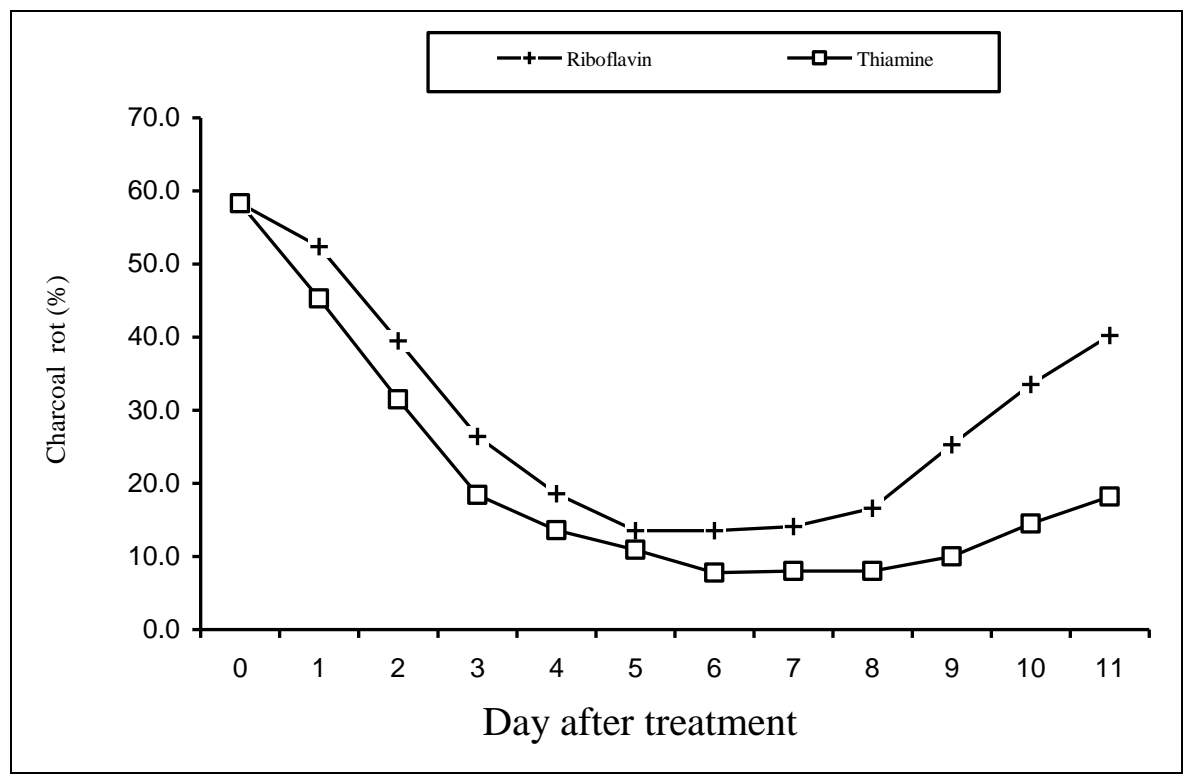

Fig. 2. Time course effect of riboflavin $(2.5 \mathrm{mM})$ and thiamine $(5 \mathrm{mM})$ on $M$. phaseolina infection.

Field experiments:

A-Effect of riboflavin and thiamine on damping-off and charcoal rot diseases and nodulation of soybean under field conditions:

The effect of riboflavin $(2.5 \mathrm{mM})$ and thiamine $(5 \mathrm{mM})$ on incidence of damping - off and charcoal rot diseases and nodulation of soybean under field conditions is shown in Table (2). The percentages of damping-off and charcoal rot severity were significantly reduced due to soaking the seeds in any of riboflavin and thiamine before sowing compared with control treatment (seed treated with water) in both seasons. In this regard, thiamine was the highest effective in reducing damping-off and charcoal rot severity than riboflavin treatment, while recorded $3.23,4.12 \%$ damping-off and 5.25, 6.05\% charcoal rot in case of thiamine and $6.45,6.96 \%$ damping-off and $9.25,12.74 \%$ charcoal rot in case of riboflavin compared with $14.33,16.41 \%$ damping-off and $26.59,28.24 \%$ charcoal rot in control in both seasons, respectively. 


\section{$B$ - Effect of riboflavin and thiamine on vegetative growth and yield parameters of soybean under field conditions:}

The treatments tested (Table 3 ) significantly improved plant height and increased number of branches and pods plant ${ }^{-1}$, weight of 100 seeds, total seed.

Also, data present in Table (2) summarize that soaked of soybean seeds in thiamine and riboflavin due to significant increase of nodule numbers plant ${ }^{-1}$, fresh and dry weight of nodules plant ${ }^{-1}$ compared with control in both seasons. Riboflavin treatment increased nodule numbers plant ${ }^{-1}\left(17.23\right.$ and 15.01 nodule plant $\left.{ }^{-1}\right)$ than thiamine treatment (14.05 and 12.93 nodule plant $\left.{ }^{-1}\right)$; in contrary thiamine treatment increased of fresh and dry weight of nodules plant ${ }^{-1}$ than riboflavin treatment in both seasons. Yield, dry seed contain of protein and oil compared with check treatment during the two experimental seasons.

In this respect, seeds previously soaking in thiamine increased all the studied characters than that treated with riboflavin in both seasons, as provided plant height from $57.23,53.36$ in check treatment to $74.25,70.45 \mathrm{~cm}$ in both seasons, respectively and increased number of branches plant ${ }^{-1}$ from $2.72,2.59$ to $3.24,3.14$ and pods number plant ${ }^{-1}$ from $58.14,52.71$ to $79.47,77.12$ in both seasons.

Also, thiamine treatment increased each of the 100 -seed weight compared with check treatment (from 13.10, $12.95 \mathrm{~g}$ to $16.27,15.97 \mathrm{~g}$ ), total seed yield (from 1035.07, 998.17 to $1589.11,1515.09 \mathrm{~kg} \mathrm{fed}^{-1}$ ) and increased percentage of protein in dry seeds from $34.29,33.64 \%$ in check treatment to $39.99,39.16 \%$ and oil contain in dry seeds from $17.59,16.51$ to $20.84,19.37 \%$ in both seasons, respectively.

\section{Biochemical changes associated with riboflavin and thiamine treatments:}

Accumulation of peroxidase (PO), polyphenol oxidase (PPO), phenylalanine ammonia lyase (PAL) enzymes, and pathogenesis related (PR) protein (chitinase), phenolic compounds and lignin in plants inoculated with $M$. phaseolina or noninoculated plants treated and untreated with riboflavin and thiamine were studied.

\section{Peroxidase activity:}

Data in Fig. (3) show that PO activity of inoculated and non-inoculated soybean plants treated with riboflavin and thiamine was higher than that of untreated plants after all time from application. Inoculated plants caused the highly PO activity than non-inoculated plants whether treated and untreated especially after 4 days from treatment with thiamine and riboflavin.

Thiamine treatment recorded the highly enzyme activity than riboflavin. The highest levels of PO were determined 8 days after treatment in all cases. The highest of PO activity was recorded in soybean plants inoculated with the pathogen and treated with thiamine at 8 th day from application (3.280 enzyme unit $\mathrm{mg}^{-1}$ protein $\mathrm{min}^{-1}$ ). In general, the enzyme activity rapid increase in the activity of defense related components until 8 days after application then decreased progressively.

\section{Polyphenol oxidase activity:}

In general, a significant increase in the activity of PPO was observed in both non-inoculated and inoculated soybean plants following treatment with riboflavin and thiamine more than control treatment (Fig. 4). PPO accumulated more markedly 
in plants treated with thiamine than riboflavin especially in inoculated plants. Also, PPO activity increase as days after application of treatment increased until $6 \underline{\text { th }}$ day then decreased progressively. Maximum levels of PPO were recorded at $6 \underline{\text { th }}$ and $8 \underline{\text { th }}$ days from application of treatments, respectively in all cases. Soybean plants treated with thiamine and inoculated with the pathogen recorded the highest level of PPO activity in 6th day from application (2.312 enzyme unit $\mathrm{mg}^{-1}$ protein $\mathrm{min}^{-1}$ ) followed by 8 th of application the same treatment (2.151 enzyme unit $\mathrm{mg}^{-1}$ protein $\mathrm{min}^{-1}$ ). On the other hand, PPO activity in inoculated plants increases markedly than noninoculated plants in all tested periods.

Table 2. Effect of soaking seeds in riboflavin $(2.5 \mathrm{mM})$ and thiamine $(5 \mathrm{mM})$ on incidence of damping-off and charcoal rot diseases, number of nodules, fresh and dry weight of nodules plant ${ }^{-1}$ during summer seasons 2009 and 2010 , under field conditions

\begin{tabular}{|c|c|c|c|c|c|c|}
\hline Treatments & 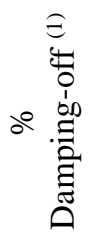 & o & 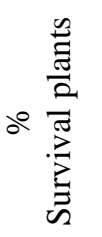 & 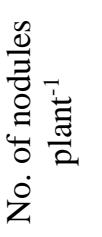 & 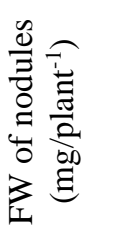 & 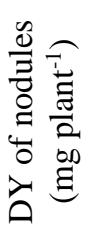 \\
\hline \multicolumn{7}{|c|}{ Summer season 2009} \\
\hline Riboflavin & 6.45 & 9.25 & 84.30 & 17.23 & 235.50 & 69.26 \\
\hline Thiamine & 3.23 & 5.25 & 91.52 & 14.05 & 248.57 & 73.01 \\
\hline Control & 14.33 & 26.59 & 59.08 & 11.18 & 168.47 & 51.76 \\
\hline LSD at 0.05 & 1.72 & 2.95 & 7.85 & 2.48 & 12.14 & 6.19 \\
\hline \multicolumn{7}{|c|}{ Summer season 2010} \\
\hline Riboflavin & 6.96 & 12.74 & 80.3 & 15.01 & 228.32 & 65.60 \\
\hline Thiamine & 4.12 & 6.05 & 89.83 & 12.93 & 237.82 & 68.44 \\
\hline Control & 16.41 & 28.24 & 55.35 & 10.48 & 160.70 & 48.96 \\
\hline LSD at 0.05 & 0.86 & 1.48 & 8.27 & 1.98 & 11.42 & 5.37 \\
\hline
\end{tabular}

${ }^{1}$ Damping-off was recorded after 30 days from planting as follows:

Damping-off $(\%)=$ Pre-emergence $(\%)+$ Post emergence $(\%)$

${ }^{2}$ Charcoal rot was recorded according to Mengistu et al. (2007) based on 0-5 scale according percentage of foliage yellowing or necrosis $(0=0 \%, 1=1-25 \%, 2=26$ $50 \%, 3=51-75 \%, 4=$ up to $76 \%, 5=$ completely dead plants $)$. 
Table 3. Effect of soaking soybean seeds in riboflavin $(2.5 \mathrm{mM})$ and thiamine $(5$ $\mathrm{mM}$ ) on plant height, number of branches, pods plant ${ }^{-1}$, weight of 100 seeds, seed yield fed ${ }^{-1}$, protein and oil percentages during summer season 2009 and 2010, under field conditions.

\begin{tabular}{|c|c|c|c|c|c|c|c|}
\hline Treatments & 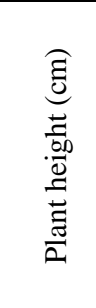 & 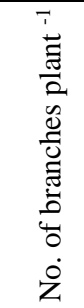 & $\begin{array}{l}\frac{n}{\overrightarrow{0}} \\
\dot{2} \\
\dot{0} \\
\dot{0} \\
\dot{0} \\
\dot{z}\end{array}$ & 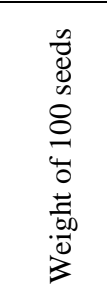 & 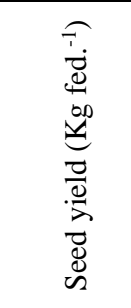 & 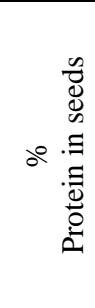 & 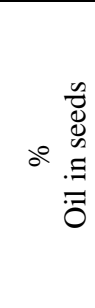 \\
\hline \multicolumn{8}{|c|}{ Summer season 2009} \\
\hline Riboflavin & 69.54 & 3.14 & 73.14 & 15.80 & 1485.54 & 37.48 & 19.65 \\
\hline Thiamine & 74.25 & 3.24 & 79.47 & 16.27 & 1589.11 & 39.99 & 20.84 \\
\hline Control & 57.23 & 2.72 & 58.14 & 13.10 & 1035.07 & 34.29 & 17.59 \\
\hline LSD at 0.05 & 5.87 & 0.07 & 6.04 & 1.77 & 63.21 & 2.46 & 1.23 \\
\hline \multicolumn{8}{|c|}{ Summer season 2010} \\
\hline Riboflavin & 65.99 & 3.04 & 68.54 & 15.59 & 1401.80 & 37.00 & 19.04 \\
\hline Thiamine & 70.45 & 3.14 & 77.12 & 15.97 & 1515.09 & 39.16 & 19.37 \\
\hline Control & 53.36 & 2.59 & 52.71 & 12.95 & 998.17 & 33.64 & 16.51 \\
\hline LSD at 0.05 & 4.44 & 0.10 & 5.93 & 1.53 & 60.83 & 2.42 & 1.17 \\
\hline
\end{tabular}

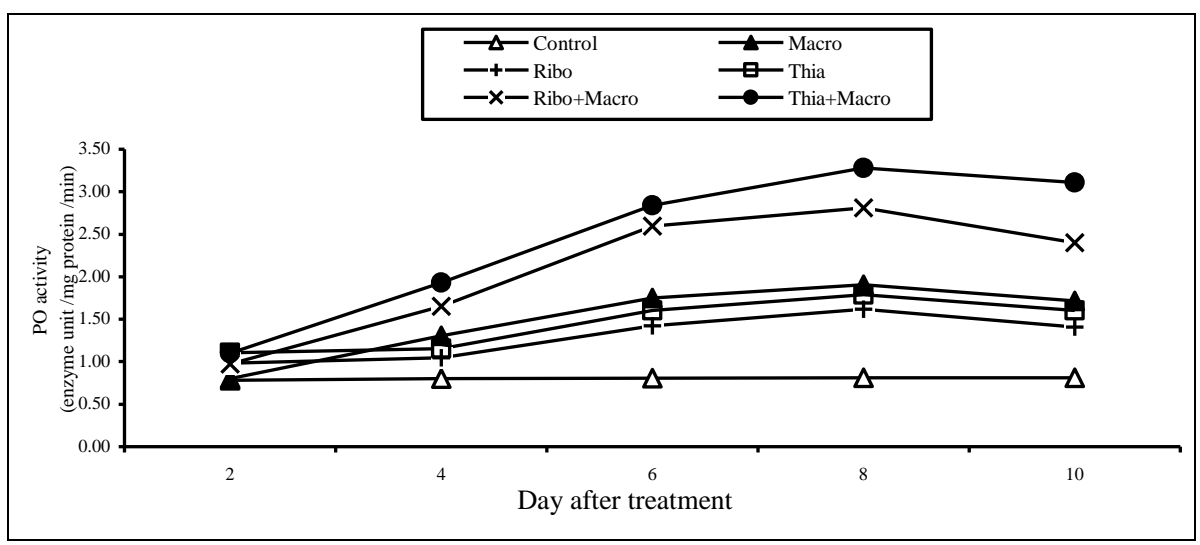

Fig 3. Effect of riboflavin $(2.5 \mathrm{mM})$ and thiamine $(5 \mathrm{mM})$ on activity of peroxidase (PO) in inoculated and non-inoculated soybean plants. (The samples were collected from both inoculated and non-inoculated plants after 2, 4, 6, 8 and 10 days after treatment). 


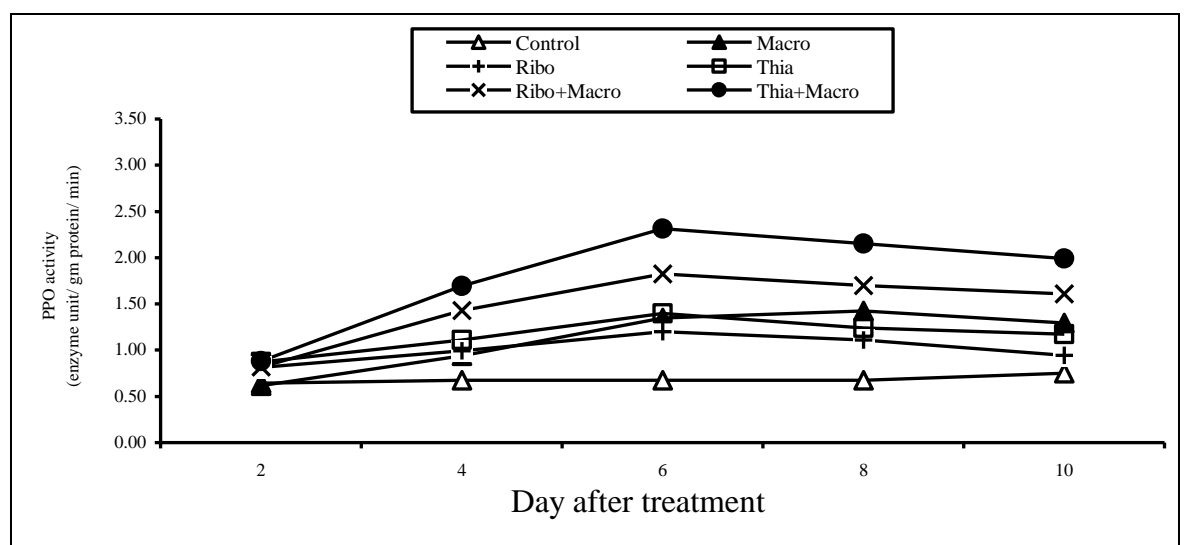

Fig 4. Effect of riboflavin $(2.5 \mathrm{mM})$ and thiamine $(5 \mathrm{mM})$ on activity of polyphenol oxidase (PPO) in inoculated and non-inoculated soybean plants. (The samples were collected from both inoculated and noninoculated plants after 2, 4, 6, 8 and 10 days after treatment).

Phenylalanine ammonia lyase activity:

Data in Fig. (5) show that the levels of PAL activity in inoculated plants were highly increased than in non-inoculated control plants until 6 $\underline{\text { th }}$ day from inoculation then decreased approximately equal in activity in 8th day from inculcation. On the other hand, PAL activity was highly significant increase in inoculated plants and treated with thiamine or riboflavin than inoculated plants only. Also, the activity of PAL increased by increasing time after application until 8 days from application then the activity decreased. Focusly, the higher activities of PAL were determined in inoculated soybean plants 8th day from treatment with thiamine and riboflavin (2.877 and 2.651 enzyme unit $\mathrm{mg}^{-1}$ protein $\mathrm{min}^{-1}$, respectively).

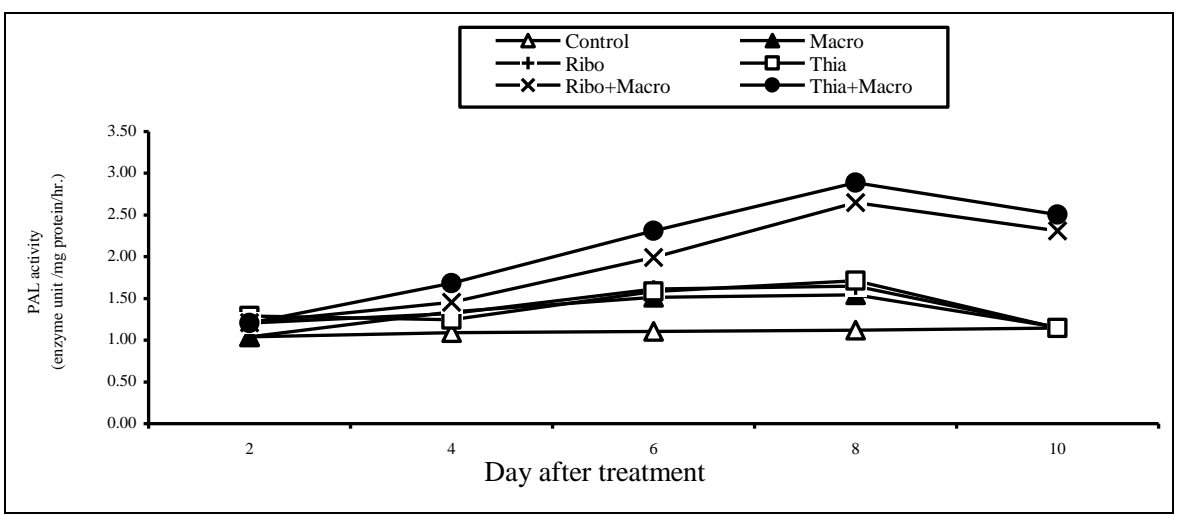

Fig. 5. Effect of riboflavin $(2.5 \mathrm{mM})$ and thiamine $(5 \mathrm{mM})$ on activity of phenylalanine ammonia lyase (PAL) in inoculated and non-inoculated soybean plants. (The samples were collected from both inoculated and non-inoculated plants after $2,4,6,8$ and 10 days after treatment). 
Chitinase activity:

In non-inoculated soybean plants, treated plants with thiamine and riboflavin exhibited enzyme activity higher than the untreated control after all tested periods of enzyme determination especially at 8 days after application (Fig. 6). In inoculated plants data show that treated plants caused significant increased of chitinase activity than that of untreated plants after all tested periods of determination. In general, soybean plants treated with riboflavin caused the higher enzyme activity than thiamine. The enzyme activity was increased at 2, 4, 6 and 8 days after application and then decreased at 10 days from application. Maximum enzyme activity was recorded after 8 days from treatment with riboflavin $\left(7.442\right.$ enzyme unit $\mathrm{mg}^{-1}$ protein $\min ^{-1}$ ) in inoculation plants followed by riboflavin treatment in inoculated plant at $10^{\text {th }}$ from application (7.002 enzyme unit $\mathrm{mg}^{-1}$ protein $\mathrm{min}^{-1}$ ).

\section{Total phenol content:}

The total phenols were measured in inoculated and non-inoculated soybean plants treated and untreated with thiamine and riboflavin (Fig. 7). Riboflavin and thiamine did not show significant role to accumulation of phenolic compounds in non-inoculated plants. However, thiamine or riboflavin pre-treated soybean plants challenge inoculated with the pathogen showed rapid increase in the accumulation of phenol compounds. The accumulation of phenols in inoculated plants was highly increased than non-inoculated plants during all determination periods tested. On the other hand, the phenol contents were exhibited at 6th day from application in inoculated and treated plants with both compounds then decreased progressively thereafter. Maximum level of phenolic compounds were recorded at $6 \underline{\text { th }}$ from applied of thiamine treatment $(3.872 \mathrm{mg} / \mathrm{gm}$ fresh weight) followed by the same treatment at $8 \underline{\text { th }}$ from treatment $(3.728 \mathrm{mg} / \mathrm{gm}$ fresh weight).

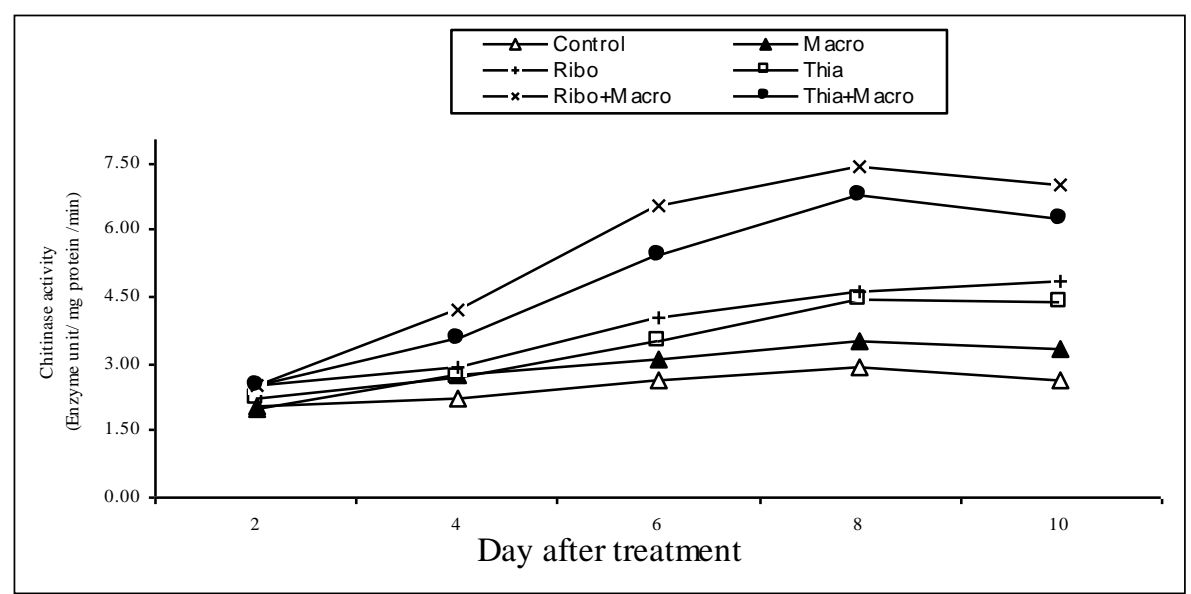

Fig. 6. Effect of riboflavin $(2.5 \mathrm{mM})$ and thiamine $(5 \mathrm{mM})$ on activity of chitanase in inoculated and non-inoculated soybean plants. (The samples were collected from both inoculated and non-inoculated plants after 2, 4, 6, 8 and 10 days after treatment).

Egypt. J. Phytopathol., Vol. 39, No. 1 (2011) 
Lignin content:

Data in Fig. (8) indicate that lignin content was increased in soybean plants treated with thiamine and riboflavin. Plants inoculated with the pathogen content highly level of lignin than non-inoculated control plants. The accumulation of lignin increased with increasing the determination periods after treatment application and/or inoculation with the pathogen. Plant treated with thiamine caused increased of lignin content than plants treated with riboflavin in inculcated or non-inoculated plants. Also, riboflavin and thiamine treatments increased of lignin content in noninoculated plants than inoculated untreated plants. The highest lignin content was recorded by thiamine treatment in inoculated plant after 10 days $(0.257 \mathrm{mg} / \mathrm{gm}$ dry weight $)$ from application followed by riboflavin treatment $(0.239 \mathrm{mg} / \mathrm{gm}$ dry weight) in the same period of treatment application.

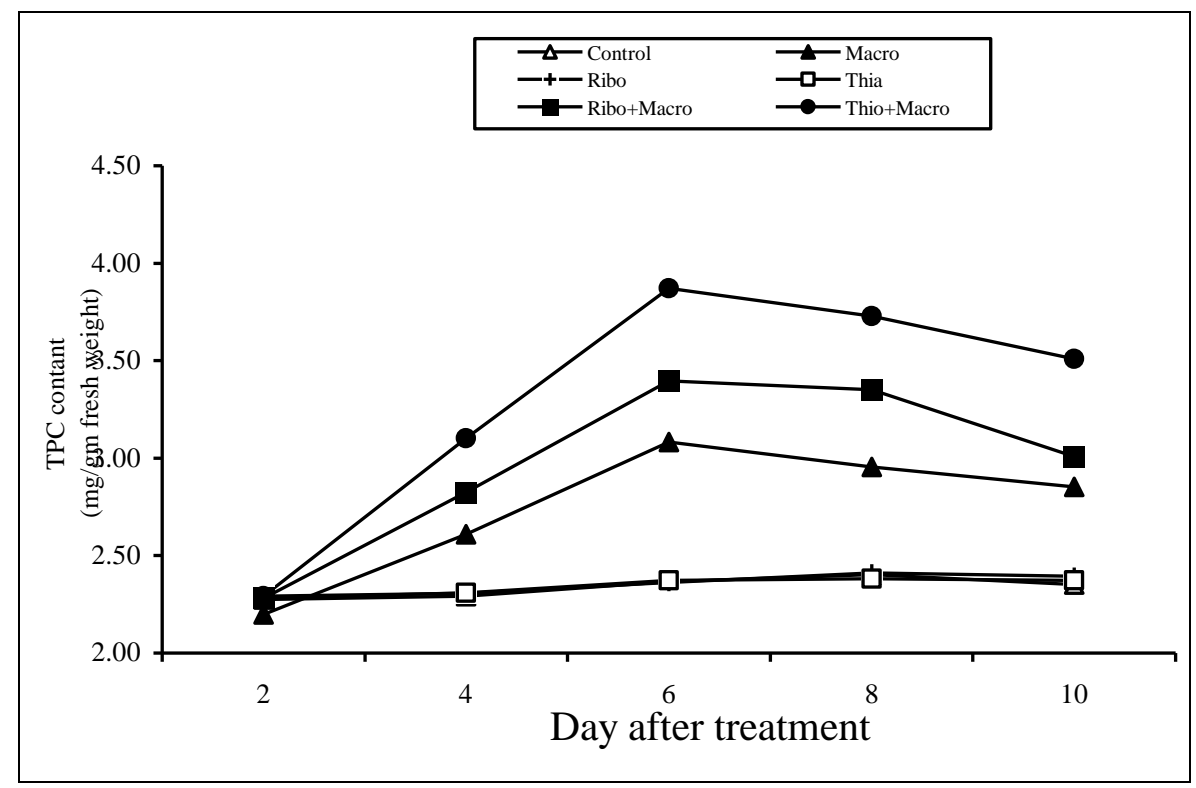

Fig. 7. Effect of riboflavin $(2.5 \mathrm{mM})$ and thiamine $(5 \mathrm{mM})$ on total phenol content (TPC) in inoculated and non-inoculated soybean plants. (The samples were collected from both inoculated and non-inoculated plants after 2, 4, 6, 8 and 10 days after treatment). 


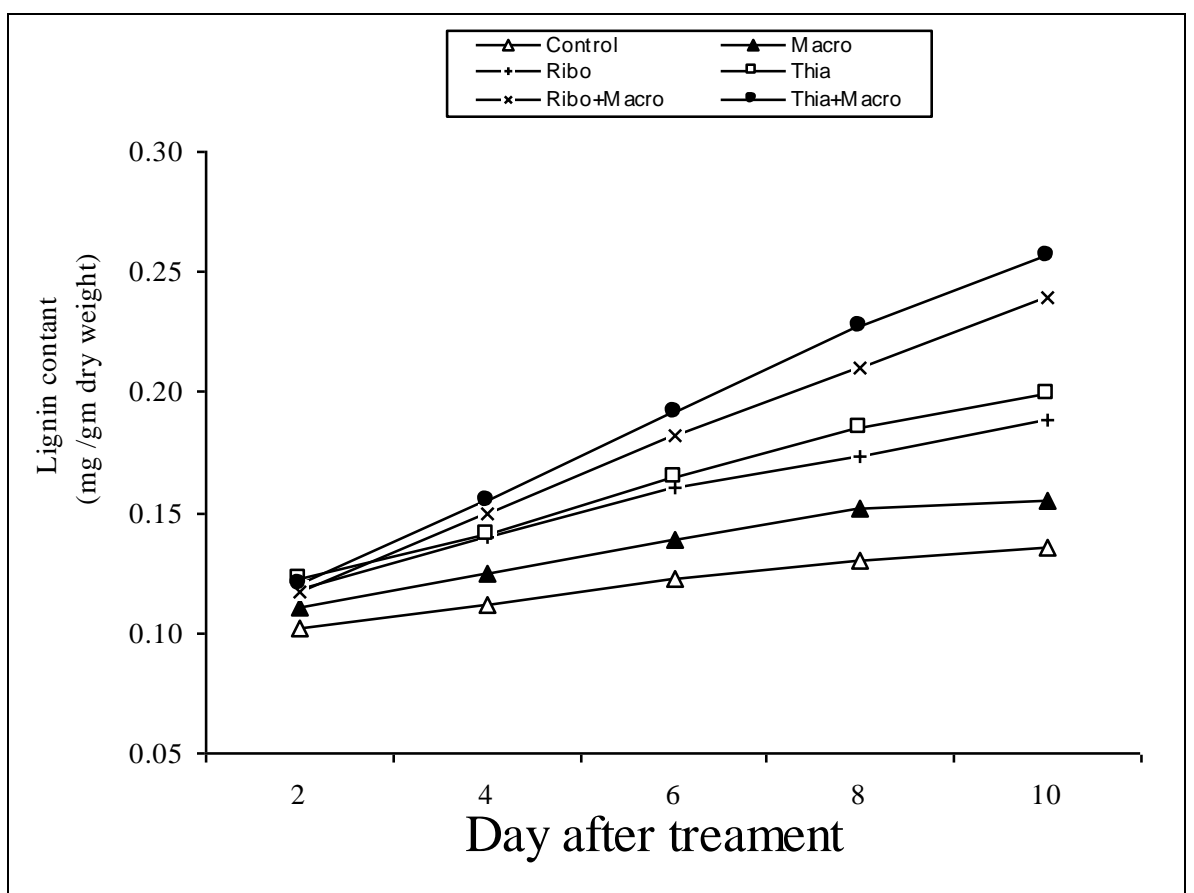

Fig. 8. Effect of riboflavin $(2.5 \mathrm{mM})$ and thiamine $(5 \mathrm{mM})$ on lignin content in inoculated and non-inoculated soybean plants. (The samples were collected from both inoculated and non-inoculated plants after 2, 4, 6, 8 and 10 days after treatment).

\section{Dis c us sion}

Soybean (Glycine max (L.) Merr.) is one of the most important legumes plants. Soil borne diseases including root rot, wilt and charcoal rot cause important considerable losses in yield. Charcoal rot is a widespread root and stem disease of soybean caused by the soil-inhabiting fungus Macrophomina phaseolina. The disease is more damaging in years with extended periods of hot, dry weather. Isolation trails from rotted soybean plants yielded 14 isolates of $M$. phaseolina conforming to other reports (Wrather et al., 2001; Mengistu et al., 2007 and ElBarougy et al., 2009). Pathogenicity test demonstrated that all the obtained isolates able to infect soybean plants caused typical charcoal rot symptoms with different percentages of disease severity.

The use of fungicides to control soilborne diseases of economically important crops has bean used in agriculture for many years. However, recently the use of chemical has been reduced for several reasons, including pollution of environment, particularly ground water and food supplies. Recently, an increasing desire to reduce the use of fungicides is seen through the attempts to develop integrated pest managements approaches, where natural resources are put to maximum use. Chemically induced resistance (IR) is a suitable strategy to utilize natural defenses

Egypt. J. Phytopathol., Vol. 39, No. 1 (2011) 
of the plant to control pathogens. This phenomenon has been studied at the molecular level and has proved to be mediated by salicylic acid and associated with a number of defense responses and genes (Ton, 2005). Induced resistance was reported to be activated by exogenous application of thiamine and riboflavin (Ahn et al., 2005, Dong and Beer, 2000 Saikia et al., (2006). Thiamine and riboflavin are promoted as a safe, reliable and non-phytotoxic plant protection agent. It was recently identified by scientists as a novel disease - control compound. Application of thiamine and riboflavin to a variety of plants before challenge with the pathogens triggered a set of plant defense reactions that resulted in the creation of a fungitoxic environment, which protect them by different (physical and / or chemical means) mechanisms (Sierra, and Vidal-Valverde, 1999).

The results of the present work indicated that both thiamine and riboflavin reduced DSI caused by artificial infection by $M$. phaseolina and increased fresh and dry weight of the plants. The efficiency of riboflavin and thiamine was varied with various concentrations. The dose effect of 0.1 to $15 \mathrm{mM}$ riboflavin and thiamine showed that 2.5 and $5.0 \mathrm{mM}$ concentration was sufficient for maximum induction of resistance, in case of riboflavin and thiamine, respectively; higher concentration did not increase the effect. In time course observation, it was observed that riboflavin and thiamine treated soybean plants were inducing resistance one day after treatment and reached its maximum level from 5 to 7 days after treatment with riboflavin and 6-8 days after treatment with thiamine. Similar results were reported by Saikia et al. (2006) who found that riboflavin at $1.0 \mathrm{mM}$ caused induction of systemic resistance in chickpea against Fusarium wilt and charcoal rot. At this concentration, riboflavin neither caused cell death of the host plant nor directly affected the pathogen's growth. In time course observation, it was observed that riboflavin treated chickpea plants were inducing resistance 2 days after treatment and reached its maximum level from 5 to 7 days and then decreased. Also, some studies observed that foliar application of riboflavin effectively controlled several diseases of tobacco (Dong and Beer, 2000). Ahn et al., (2005) demonstrated that thiamine induces SAR and vitamin B1 functions as an activator of plant disease resistance. They described that thiamine treated rice, Arabidopsis thaliana and vegetable crops showed resistance to fungal, bacterial and viral infections.

Under field conditions, both thiamine $(5 \mathrm{mM})$ and riboflavin $(2.5 \mathrm{mM})$ significantly reduced damping - off and charcoal rot severity and increased nodule numbers, fresh and dry weight of nodules plant ${ }^{-1}$. Also, these treatments increased vegetative growth and yield parameters, where improved plant height and increased number of branches and pods plant ${ }^{-1}$, weight of 100 seeds, total seed yield, dry seed contain of protein and oil during the two experimental seasons (2009 and 2010). Thiamine treatment was better than riboflavin in all cases except nodule numbers plant $^{-1}$, where riboflavin was the pest.

Several mechanisms that mediate the disease protection induced by different chemicals have been demonstrated, including blocking of disease cycle, the direct inhibition of pathogen growth (Thompson et al., 2000) and the induction of resistance to plant against pathogen infection (Ahn et al., 2005). 
Thiamine confers systemic acquired resistance (SAR) on susceptible plants through priming, leading to rapid counterattack against pathogen invasion and perturbation of disease progress (Ahn et al., 2005). Priming reduces the metabolic cost required for constitutive expression of acquired resistance. Thiamine treatment and subsequent pathogen invasion triggered hydrogen peroxide accumulation, callose induction, and PR1/PAL1 transcription activation in Arabidopsis mutants insensitive to jasmonic acid (jar1), ethylene (etr1), or abscisic acid (abi3-3), but not in plants expressing bacterial NahG and lacking regulation of SAR (npr1 [nonexpressor of PR genes 1]) (Ahn et al., 2007).

Recent studies of riboflavin indicate the function of the compound in mediating resistance signal transduction. Riboflavin is an antioxidant induces resistance in plants against pathogen (Packer et al., 1996). Riboflavin is a cofactor of enzyme flavoproteins, some of which catalyze lipid peroxidation a main process in producing ROIs that serve as a signaling network in plant immune responses (Alvarez et al., 1998). The role of riboflavin in peroxidation is antagonistic to its role in antioxidation (Dong and Beer, 2000). Balance between both reactions should be a part of the signaling mediation and may affect whether programmed cell death occurs. Glycosylated forms of riboflavin, which are considered unimportant in plant (Sierra and Vidal-Valverde, 1999), may serve as a signal-storage compound. This function may be similar to that of calmodulins and glycosylated SA, which function in the $\mathrm{Ca}^{+2}$ and SA signal storage, respectively. Finally, the universal existence of flavin kinases, required to activate flavoproteins may be linked with protein kinase cascades, which are a typical mode of signal transduction. Therefore, there is a reasonable basis for riboflavin to mediate a distinct signal transduction pathway.

Zhang et al. (2008) shown that riboflavin induces pathogen resistance in Arabidopsis thaliana against infection by Pseudomonas syringae pv. tomato DC3000 (Pst) through the expression of defense response genes and cellular defense events, including $\mathrm{H}_{2} \mathrm{O}_{2}$ burst, hypersensitive cell death (HCD), and callose deposition in the plant. On the other hand, Saikia et al. (2006) reported that accumulation of phenols and greater activities of phenylalanine ammonia lyase (PAL) and peroxidase enzymes may be one of the basic ways participate in the action of riboflavin in inducing resistance in chickpea plants against Fusarium wilt and charcoal rot.

In this study, it was showed that induced plants resulted in a significant increase in PO, PPO, PAL and chitanase activities in inoculated and non - inoculated plants with $M$. phaseolina and these components begin to accumulate 2 days after treatment and reached maximum levels at $8,6,8$ and 8 days for PO, PPO, PAL and chitanase, respectively then the activities of these enzymes were decreased progressively. Thiamine treatment increased the activities of PO, PPO, PAL and chitanase in inoculated or non-inoculated plants than riboflavin treatment. Also, it has found comparatively least disease severity at 6 to 8 days and 5 to 7 days after treatment with thiamine and riboflavin respectively, this indicated that thiamine and riboflavin mediated induced resistance in soybean plants was related with the increase in PO, PPO, PAL and chitanase activities. On the other hand, total phenols

Egypt. J. Phytopathol., Vol. 39, No. 1 (2011) 
and lignin increased in soybean plants inoculated with $M$. phaseolina and treated with thiamine and riboflavin. The highest accumulation of phenols was recorded $6 \underline{\text { th }}$

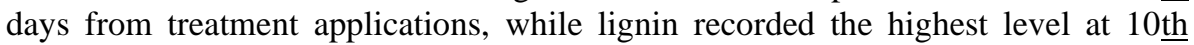
days from application.

In conclusion, the present study provides further evidence that may facilitate applying simple non-toxic chemicals as thiamine and riboflavin for controlling charcoal rot diseases in soybean. Their low cost, low toxicity to the man and environmental pollution makes them ideal seed soaking for disease control under field conditions and increased seed yield and seed content from oil and protein.

\section{R e f e r e n c e s}

A.O. A. C. 1990. Official Methods of Analysis Association of Official Analytical Chemists. $15^{\text {th }}$ Ed. Inc. Wash. D. C. Nutrient Cycling in Agro Ecosystems, 56 (3): 263-275.

Ahn, I. P.; Kim, S. and Lee, Y. H. 2005. Vitamin B1 functions as an activator of plant disease resistance. Plant Physiol., 138: 1505-1515.

Ahn, P.; Kim, S.; Lee, Y. and Suh, S. 2007. Vitamin B1-induced priming is dependent on hydrogen peroxide and the NPR1 gene in Arabidopsis. Plant Physiology, 143 (2): 838-848.

Alvarez, M. E.; Pennell, R. I.; Meijer, P. J.; Ishikawa, A.; Dixon, R. A. and Lamb, C. 1998. Reactive oxygen intermediates mediate a systemic signal network in the establishment of plant immunity. Cell, 92:773-784.

Barnett, H L. and Hunter, B. B. 1986. Illustrated Genera of Imperfect Fungi. 4 th Ed., Macmillan Publishing Co., New York.

Biles, C.L. and Martyn, R. D. 1993. Peroxidase, Polyphenoloxidase and shikimate dehydrognase isozymes in relation to tissue type, maturity and pathogen induction of watermelon seedling. Plant Physiol. Biochem., 31: 499-506.

Bradford, M. 1976. A rapid and sensitive method for the quantitation of Microgram quantities of protein utilizing the principle of protein dye binding. Anal. Biochem., 72:248-250.

Cavalcanti, F. R.; Resendea, M. L. V.; Carvalhoc, C. P. S.; Silveirab, J. A. G. and Oliveira, J. T. A. 2007. An aqueous suspension of Crinipellis perniciosa mycelium activates tomato defense responses against Xanthomonas vesicatoria. Crop Prot., 6:729-738.

Delaney, T. P. 1997. Genetic dissection of acquired resistance to disease. Plant. Physiol., 113:5-12

Dhingra, O. D. and Sinclair, J. B. 1985. Basic Plant Pathology Methods. CRC, Boca Raton, Florida, USA. 
Dong, H. and Beer, S. V. 2000. Riboflavin induces disease resistance in plants by activating a novel signal transduction pathway. Phytopathology, 90:801-811.

Dubey, R.C.; Harish, K. and Pandey, R. R. 2009. Combined effect of soil solarization and neem amendment on survival of Macrophomina phaseolina sclerotia and growth of soybean. Nature and Sci., 7 (11): 52-57.

El-Abady, M. I.; Seadh, S. E.; Attia, A. N. and El-Saidy, Aml E. A. 2008. Impact of foliar fertilization and its time of application on yield and seed quality of soybean. The $2^{\text {ed }}$ Field Crops Conference, FCRI, AV, Giza, Egypt, 14-16 Oct.: 357-375.

El-Barougy, Ebtehag; Awad, Nemat, M.; Turky, Azza Sh. and Hamed, Hoda A. 2009. Antagonistic activity of selected strains of Rhizobacteria against Macrophomina phaseolina of soybean plants. American - Eurasian J. Agric. \& Environ. Sci., 5 (3): 337-347.

El-Baz, Sahar, M. 2007. Induction of resistance in some soybean varieties against root rot diseases by some chemical inducers. Egypt. J. of Appl. Sci., 22 (1): 6880 .

Francl, L.J.; Wyllie, T. D. and Rosenbrock, S. M. 1988. Influence of crop rotation on population density of Macrophomina phaseolina in soil infested with Heterodora glycines. Plant Dis., 72:760-764.

Gastaldi, G.; Laforenza, U.; Gasirola, D.; Ferrari, G.; Tosco, M. and Rindi, G. 1999. Energy depletion differently affects membrane transport and intracellular metabolism of riboflavin taken up by isolated rat enterocytes. J. Nutr., 129:406409.

Gauillard, F.; Richard-Forget, F. and Nicolas, J. 1993. New spectrophotometric assay for polyphenol oxidase activity. Anal. Biochem., 215:59-65.

Gomez, K.A. and Gomez, A.A. 1984. Statistical Procedures for Agricultural Research.. A Lviley. Interscience Publication, New York, pp.678.

González, S. 2006. Bromuro de metilo: un fumigante en retirada. Colección Libros INIA N 20.173 p. Instituto de Investigaciones Agropecuarias, Santiago, Chile.

Hammerschmidt, R.; Nuckles, E. M. and Kuc, J. 1982. Association of enhanced peroxidase activity with induced systemic resistance of cucumber to Colletotrichum lagenarium. Physiol. Plant Pathol., 20:73-82.

Hewidy, M. A.; Ismail, I. A.; Morsy, K. M.; Mahmoud, Nagwa M. A. and ElGalaly, Ola A. M. 2003. Effect of seed treatment with some fungicides, biocides and saponin in controlling damping-off on soybean disease. J. Agric. Sci. Mansoura Univ., 28 (4): 2733-2746.

Karliner, J. 1997. The barons of bromide: The corporate forces behind toxic poisoning and ozone depletion. The Ecologist, 27:90-98.

Egypt. J. Phytopathol., Vol. 39, No. 1 (2011) 
Kendig, S. R.; Rupe, J. C. and Scott, H. D. 2000. Effect of irrigation and soil water stress on densities of Macrophomina phaseolina in soil and roots of two soybean cultivars. Plant Dis., 84:895-900.

Liken, M. and Perdith, A. 1999. Fractionation of spruce trichloroacetic lignin. Acta Chin. Slov., 46 (1): 87-97.

Mengistu, A.; Ray, J. D.; Smith, J. R. and Paris, R. L. 2007. Charcoal rot disease assessment of soybean genotypes using a colony-forming unit index. Crop Sci., 47:2453-2461.

Muthomi, J. W.; Oteino, P. E., Chemining, Wa G. N.; Nderitu, J. H. and Wagacha, J. M. 2007. Effect of legume root rot pathogens and fungicide seed treatment on nodulation and biomass accumulation. J. of Biological Sciences, 7 (7): 11631170 .

Nassiuma, D. and Wasike, W. 2002. Stability assessment of soybean varieties in Kenya, Afr. Crop Sci. J., 10 (2): 139-144.

Packer, L.; Podda, M.; Kitazawa, M.; Thiele, J.; Saliou, C.; Witt, E. and Traber, M. G. 1996. Vitamin E and the metabolic antioxidant network. In: Molecular Mechanism of Signaling and Membrane Transport. K.W.A. Wirtz. pp. 283-304, Springer-Verlag, Berlin.

Ryals, J. A.; Neuenschwander, U. H.; Willits, M. G.; Molina, A.; Steiner, H. Y. and Hunt, M. D. 1996. Systemic acquired resistance. Plant Cell, 8:1809-1819.

Saikia, R.; Yadav, M.; Varghese, S.; Singh, B. P. and Gogoi, D. K.; Kuma, R. and Arora, K. D. 2006. Role of riboflavin in induced resistance against Fusarium wilt and charcoal rot diseases of chickpea. Plant Pathol. J., 22 (4): 339-347.

Sierra, I. and Vidal-Valverde, C. 1999. Kinetics of free and glycosylated B6 vitamers, thiamin and riboflavin during germination of pea seeds. J. Food Sci. Agric., 79:307-310.

Sweets, L. 2008. Early season soybean diseases. Integrated Pest and Crop Management, 18 (12): 82.

Thompson, J. E.; Fahnestock, S.; Farrall, Liao D. I., Valent, B. and Jordan, D. B. 2000. The second naphthol reductase of fungal melanin biosynthesis in Magnaporthe grisea: tetra hydroxy naphthalene reductase. J. Biol. Chem., 275:34867-34872.

Todd, T.C. 1993. Soybean planting date and maturity effects on Heterodera glycines and Macrophomina phaseolina in southeastern. Kansas. J. Nematol., 25:731737.

Ton, J.; Jakab, G.; Toquin, V.; Flors, V.; Iavicoli, A.; Maeder, M.; Metraux, J. and Mauch-Mania, B. 2005. Dissecting the $\beta$-aminobutyric acid-induced priming phenomenon in Arabidopsis. The Plant Cell, 17: 987-999.

Egypt. J. Phytopathol., Vol. 39, No.1 (2011) 
Urbanek, H.; Kuzniak-Gebarowska, E. and Herka, H. 1991. Elicitation of defense responses in bean leaves by Botrytis cinerea polygalacturonase. Acta Physiol. Plant, 13:43-50.

Wirth, S. J. and Wolf, G. A. 1992. Micro-plate calorimetric assay for endo-acting cellulase, xylanase, chitinase, $\beta$-1, 3-glucanase and amylase extracted from forest soil horizons. Soil. Biol. Biochem., 24: 511-519.

Wrather, J. A.; Anderson, T. R.; Arsyad, D. M.; Tan, Y.; Ploper, L. D.; Porta-Puglia, A.; Ram, H. H.; and Yorinori, J. T. 2001. Soybean disease loss estimates for the top 10 soybean-producing countries in 1998. Canadian Journal of Plant Pathology, 23:115-121.

Zhang, S.; Yang, X.; Sun, M.; Sun, F.; Deng, S. and Dong, H. 2008. Riboflavininduced priming for pathogen defense in Arabidopsis thaliana. J. Integr. Plant Biol., 1-8.

\section{Corresponding author: Abdel-Monaim, M.F}

E-mail: fowzy2008@yahoo.com 


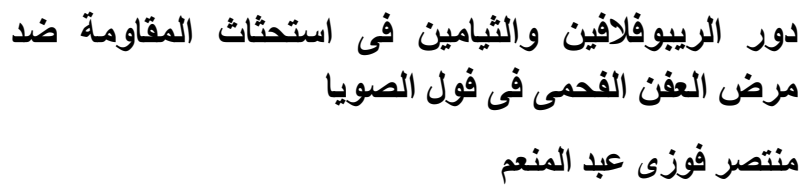

معهز بحوث امراض النباتات ـ مركز البحوث الزراعيةـ جيزة- مصر.

يعتبر فول الصويا أحد المحاصيل البقولية الهامة و التى تحتوى على نسبة عالية

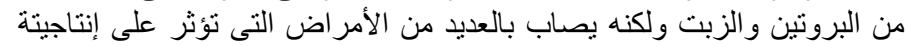

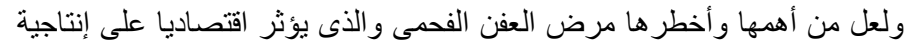

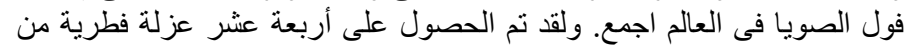

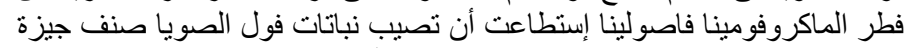

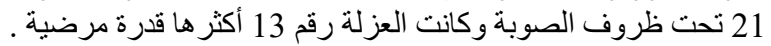

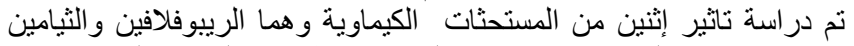

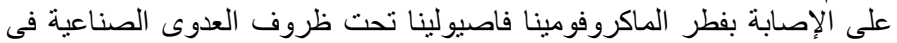

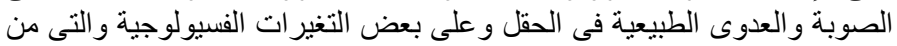

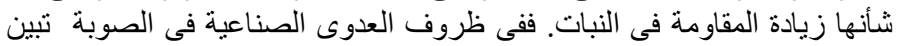

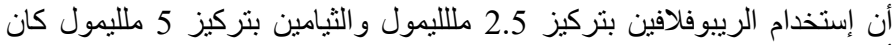

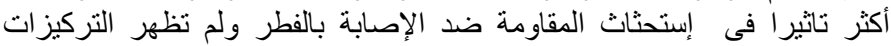

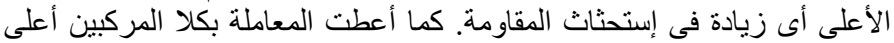

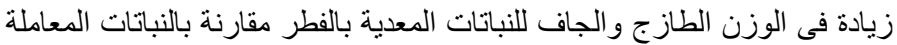

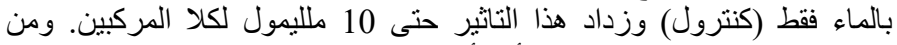

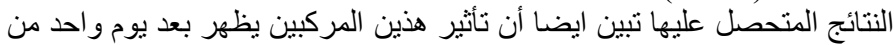

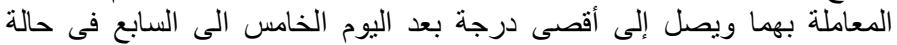

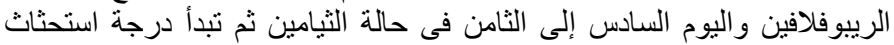

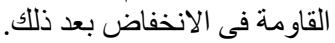

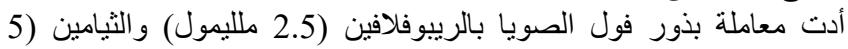

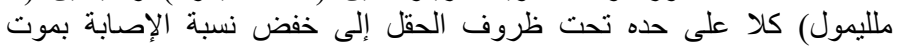

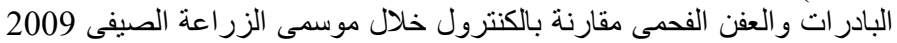

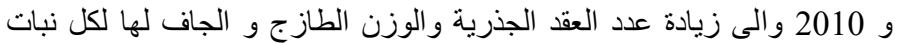

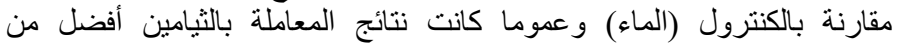

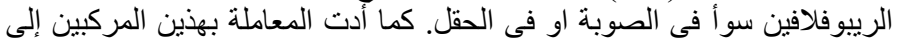

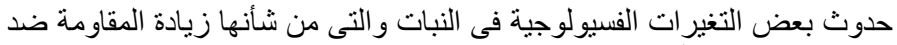

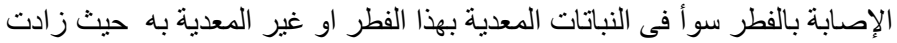

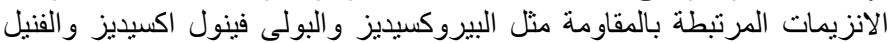

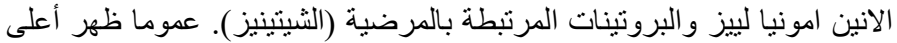

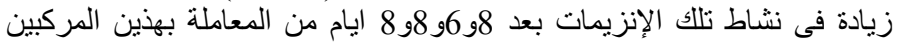

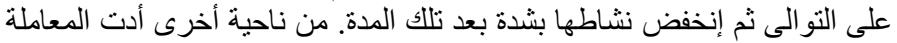

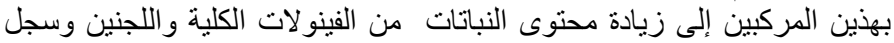

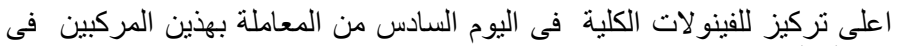

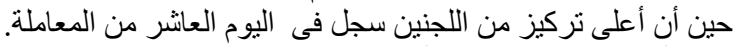

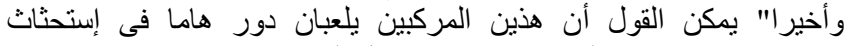
المقاومة ضد الإصـابة بهذا المرض فى نباتات فول الصويا.

Egypt. J. Phytopathol., Vol. 39, No.1 (2011) 